American Journal of Applied Sciences 9 (2): 168-176, 2012

ISSN 1546-9239

(C) 2012 Science Publications

\title{
Forecast and Performance of Wind Turbines
}

\author{
${ }^{1}$ Ahilan, T., ${ }^{2}$ S. Arumugham and ${ }^{3} \mathrm{R}$. Suja Manimalar \\ ${ }^{1}$ Tamizhan College of Engineering and Technology Chenbagaramanputhhor, \\ Kanyakumari District-629304, Tamil Nadu, India \\ ${ }^{2}$ PET Engineering College, \\ ${ }^{3}$ Department of EEE, PET Engineering College, \\ Vallioor-627117, Tirunelveli District, Tamil Nadu, India
}

\begin{abstract}
Problem statement: Wind energy industry is a nonprofit organization that works hands-on with local and community based wind projects, providing technical support to create an understanding of wind energy opportunities for rural economic benefit. This study provides a detailed vision of the global wind power market and the Indian wind market in particular. It also helps in analyzing and forecasting key metrics relating to the installed capacities, market size and growth. Approach: It helps lay the foundation to build markets for locally owned wind projects in the southeast of Tamil Nadu as well as to help rural landowners and communities benefit more from corporate owned wind projects. As part of this effort, this study organizes state, regional and national wind energy for aimed at moving the wind energy policy and project development dialogue forward, especially regarding community wind projects. Results: This study is designed to give an overview of the wind energy industry and the many benefits and challenges to wind power development in India today. Yet most research in the wind industry remains focused on near term issues, while energy system models that focus on century-long time horizons undervalue wind by imposing exogenous limits on growth. This study fills a critical gap in the literature by taking a closer look at the importance, growth and tariff of large-scale wind. The report helps to comprehend the wind turbine industry and the regulatory framework regarding the wind market in India. It offers interesting results on the market share of the top manufacturers in the India wind turbine industry. Additionally, it also provides the profiles of ten major wind turbine companies in India. Conclusion/Recommendations: This has been an ongoing process to discover the best combination for a given environment in which the wind turbine has to operate and with various challenges met, India would be in a better position to develop and carry forward its own determined initiatives to better the prospects of the wind turbine technology in the coming years. This sectoral innovation systems framework is especially useful tool for analyzing the growth of wind turbine industry and in its essence to preserve the environment with reduction in carbon dioxide emissions.
\end{abstract}

Key words: Wind power, wind energy, wind turbine, turbine industry, installed capacities, rural landowners, wind energy, remains focused, large-scale wind

\section{INTRODUCTION}

Nearly two decades ago the Indian economy was snatched back from the brink of a composite economic crisis. The Indian Government undertook some hardhitting liberalization measures that would have been unthinkable in a business as usual political landscape. Largely as a result of those actions, today India is in a position to be counted as one of the 'emerging economies'. Successive governments have looked towards locking in an average economic growth rate of at least $6-8 \%$, up from $3.5 \%$ from the 1950 s through the 1980s. The original objective of the 11th Five Year
Plan (2007-2012) was to achieve a GDP growth rate of $9 \%$ over this period. This was revised to $8.1 \%$ last year by the Planning Commission. Electricity demand has continuously outstripped production and a peak energy shortage of around $12.7 \%$ prevailed in 2009-10. To meet this shortfall as well as the National Electricity Policy target of 'Electricity for All by 2012, the cleanest options available to India are Renewable Energy Technologies (RETs). For the government to seriously consider meeting its promise of electricity for all by 2012, renewable energy options including wind power will have to play a crucial role in India's emerging energy mix. Not only are they

Corresponding Author: Ahilan, T., Tamizhan College of Engineering and Technology Chenbagaramanputhhor, Kanyakumari District-629304, Tamil Nadu, India Tel: +919443527560 
environmentally sound but also their project gestation periods are significantly shorter than those for thermal or nuclear power plants.

According to the Ministry of New and Renewable Energy (MNRE), today the share of renewable based capacity is $10.9 \%$ (excluding large hydro) of the total installed capacity of $170 \mathrm{GW}$ in the country, up from $2 \%$ at the start of the 10th Plan Period (2002-2007). This includes 13,065.78 MW of wind, 2,939 MW of small hydro power, 1,562 MW of (bagasse based) cogeneration, $997 \mathrm{MW}$ of biomass, 73.46 MW of 'waste to power' and 17.80 MW of solar PV for grid connected renewable at the end of 2010. The originally stated cumulative target for the current plan period was to add $92 \mathrm{GW}$ of new capacity of which about $14 \mathrm{GW}$ was to come from renewable sources. Given the right mix of regulatory and institutional support, renewable sources could meet the proposed capacity addition of $14 \mathrm{GW}$ from renewable energy before the end of the 11th five year plan-period (2007-2012) (GWEC, 2011). This would bring the total share of renewable energy sources upto $15 \%$ of the new installed capacity in the 11th plan-period.

India's position in world ranking: Wind energy sector in India has grown at a tremendous rate over the last one decade. It now contributes over $70 \%$ of the total renewable energy installed capacity in India. The growth has been a result of variety of incentives being offered by various state governments. Governments in states with significant wind energy resources have been offering financial incentives like tax breaks, preferential feed-in tariffs and duty waivers to wind energy project developers. And while the wind energy sector is the most mature among all the renewable energy sectors in India, there is still a massive scope of expansion in this sector. The wind energy resources have been gravely underestimated at around $49 \mathrm{GW}$. The wind resources estimation done by the Indian government was based on the mast heights of $50 \mathrm{~m}$ whereas today wind turbines with hub heights of over 80 meters are available. According to the World Institute of Sustainable Energy India's onshore wind energy resources are between 65-100 GW.

Policies announced by the Central government are also likely to fuel capacity addition in the wind energy sector. The state governments have been obligated to procurement a set minimum percentage of their energy consumption from renewable energy sources, under the Renewable Purchase Obligation (RPO). The state governments can set their own targets but need to increase those targets by at least one percent every year. The states which fail to fulfill their RPOs must purchase Renewable Energy Certificates from renewable energy-based power plants. Many states with substantial wind energy resources have announced wind-specific RPO targets.

Several major wind energy technology companies have set up base in India. Companies like GE Wind, Gamesa, Enercon, Siemens, Suzlon, Kenersys and Vestas have launched latest and state-of-the-art products for the project developers. Therefore, it is safe to say that capacity addition in the wind energy sector in India is likely to continue at a rapid pace. However, whether the installed capacities projected in the GWEC report are achieved would depend on the government policies in the medium to long-term. According to experts in wind energy in India, the performance in 2008 is hardly surprising, given the problems on the ground in different States. Local issues and tariffs continue to be the main problem areas for the wind energy sector in the country (The Hindu Business Line, 2011).

Worldwide wind capacity reached 215,000 Megawatts (MW) by the end of June 2011. The first six months of 2011 added 18,405 MW of wind power capacity. This increase represents $15 \%$ more than in the first half of 2010, when only 16,000 MW were added. Global wind capacity grew by $9.3 \%$ within six months and by $22.9 \%$ on an annual basis. According to the report, five countries-China, the United States, Germany, Spain and India-continue to do the market and the demand for wind power. Together, those countries comprise $74 \%$ of the global world capacity. China continues to dominate the world market for wind power. In the first half of 2011, it added $8 \mathrm{GW}$ of capacity while the United States added $2.3 \mathrm{GW}$. Table 1 shows the position of India globally which provides the details of capacity addition in 2011.

Wind energy currently meets $5.3 \%$ of the EU's electricity consumption from an installed capacity of 84.3 GW. The European Wind Energy Association's scenarios show that wind energy in 2020 should meet $15.7 \%$ of EU electricity demand from $230 \mathrm{GW}$ and by $2030,28.5 \%$ from $400 \mathrm{GW}$. Indeed, EWEA believes wind energy can provide half of Europe's power by 2050, with the remainder from other renewable sources. To ensure the continued buoyancy of the wind energy sector and the path to $100 \%$ renewable in 2050 , EU renewable legislation is needed now for the period after 2020. This should follow the successful legislation so far by setting an ambitious, binding renewable target for 2030 .

In the second half of 2011, an additional capacity of $25500 \mathrm{MW}$ is expected to be erected worldwide, which would bring new annual installations to $43^{\prime} 900$ MW, compared with 37'642 MW in the year 2010. The total installed wind capacity is projected to reach 240 '500 MW by the end of this year. This capacity can cover almost $3 \%$ of the electricity demand all over the world (Half Yearly Report, 2011). 
Am. J. Applied Sci., 9 (2): 168-176, 2012

Table 1: Ranking of top ten countries according to total capacity

\begin{tabular}{lllccrr}
\hline Position & Country & $\begin{array}{l}\text { Total capacity by } \\
\text { June 2011(MW) }\end{array}$ & $\begin{array}{l}\text { Added capacity firs } \\
\text { half 2011 (MW) }\end{array}$ & $\begin{array}{l}\text { Total capacity end } \\
\text { 2010 (MW) }\end{array}$ & $\begin{array}{l}\text { Added capacity } \\
\text { half 2010 (MW) }\end{array}$ & $\begin{array}{l}\text { Total capacity end } \\
\text { end 2009 (MW) }\end{array}$ \\
\hline 1 & China & 52,800 & 8,000 & 44,733 & 7,800 & 25,810 \\
2 & USA & 42,432 & 2,252 & 40,180 & 1,200 & 35,159 \\
3 & Germany & 27,981 & 766 & 27,215 & 660 & 25,777 \\
4 & Spain & 21,150 & 480 & 20,676 & 400 & 19149 \\
5 & India & 14,550 & 1,480 & 13,065 & 1,200 & 4,807 \\
6 & Italy & 6,200 & 460 & 5,797 & 450 & 4,574 \\
7 & France & 6,060 & 400 & 5,660 & 500 & 3,092 \\
8 & United kingdom & 5,707 & 504 & 5,203 & 500 & 3,319 \\
9 & Canada & 4,611 & 603 & 4,008 & 310 & 230 \\
10 & Portugal & 3,960 & 260 & 3,702 & 21,852 & 1537 \\
Rest of the world & 29,500 & 3,200 & 26,441 & 16,750 & 159,766 & \\
Total & 215,000 & 18,405 & 196,682 & & \\
\hline
\end{tabular}

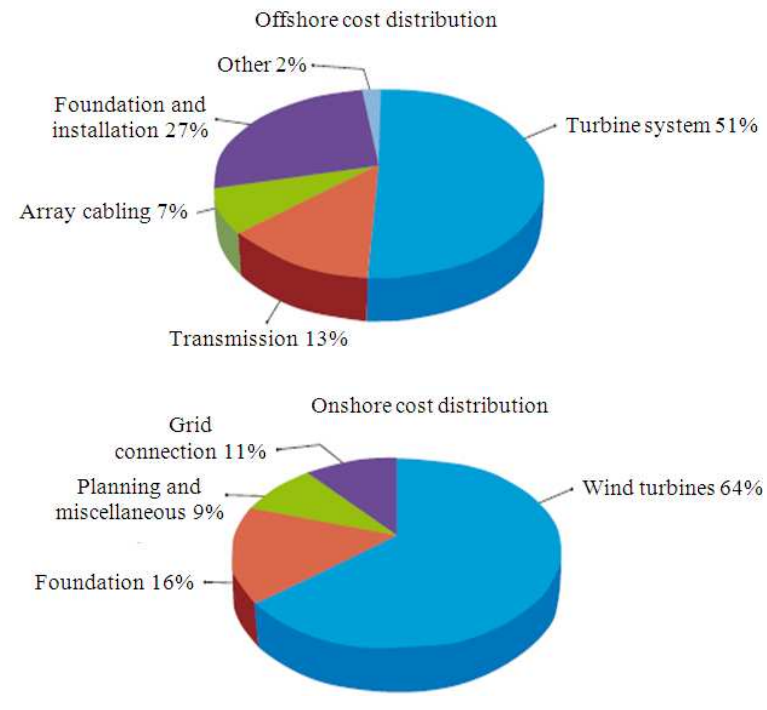

Fig. 1: Cost distribution of offshore and onshore wind projects

Offshore prospects in India: While designing wind turbines for offshore applications, it is important to note several other additional important factors. The foremost is of course the sea state and marine conditions. Other equally important aspect is the evacuation arrangements and the operation and maintenance aspects. Unlike the onshore projects, the cost of wind turbine forms only about $60-64 \%$ of the project cost. The evacuation facilities will range between $20-25 \%$ depending on the distance from the shore and as to whether on AC or DC bus is employed. High voltage DC transmission can be considered as an alternative for transmitting power for distances more than $50 \mathrm{k} \mathrm{m}$ sec from the shore. Foundations again are expected to cost less on a per KW basis for larger wind turbines as the water depth goes up. Foundation costs will be in the range of 25$27 \%$ of the project cost. Project management and other expenditure will be at about 9\%. The detailed economics of offshore and onshore wind power projects are given in Fig. 1.

About 53\% of electric power in India is generated from coal and lignite based steam thermal plants, which contribute a lot to air pollution. The need of the hour is a cleaner and renewable source of energy, in which off shore wind power can play a major role. The onshore wind power potential for India has been estimated as $15000 \mathrm{MW}$ ( $<60 \mathrm{~m}$ depth). There are many potential sites in Indian waters and still this huge potential remains untapped (Awesome Inc., 2011).

India is blessed with a coastline of about $7,600 \mathrm{~km}$. Under a National wind monitoring programme, winds have been measured at 54 locations on the coastline In Wind Chronicle, 2008/09. The western coastline has modest potential at sea level. Measurements along the coastal Kerala and Karnataka have shown marginal site indicating that winds are rather poor in the first hundred meters. Elevated hills of Goa also exhibit similar trends. Coastline around Gujarat has reasonable potential, but is prone to cyclonic conditions that can be very severe. East coast also has a modest potential but is prone to cyclonic conditions, which is again not very comfortable situation.

The southern tip of India starting from Kanyakumari up to Rameshwaram has shown some promising values. Rameshwaram indicates wind power density of $603 \mathrm{~W} \mathrm{~m}^{-2}$ at $50 \mathrm{~m}$ agl and Kanyakumari has shown wind power density in the range of $370 \mathrm{~W} \mathrm{~m}^{-2}$ at $30 \mathrm{~m}$ agl. Table 2 and 3 indicates the wind characteristics at Kanyakumari and Rameshwaram at different altitude from ground level for the period of January 2010 to December 2010.

New players: The wind turbine equipment industry in the country is currently undergoing a change with the new players entering the market. Many companies, some with European tie-ups, have either set up turbines of $1 \mathrm{MW}$ and above, or are in the process of doing so. 
Am. J. Applied Sci., 9 (2): 168-176, 2012

Table 2: Wind characteristics at kanyakumari station

\begin{tabular}{|c|c|c|c|c|}
\hline \multirow[b]{2}{*}{ Month } & \multicolumn{2}{|l|}{ Level $\mathrm{m}$ agl $10 \mathrm{~m}$} & \multicolumn{2}{|l|}{ Level $\mathrm{m}$ agl $30 \mathrm{~m}$} \\
\hline & Wind speed $(\mathrm{m} / \mathrm{sec})$ & Wind power density $\left(\mathrm{W} / \mathrm{m}^{2}\right)$ & Wind speed $(\mathrm{m} / \mathrm{sec})$ & Wind power density $\left(\mathrm{W} / \mathrm{m}^{2}\right)$ \\
\hline January & 5.07 & 187.0 & 8.06 & 473.1 \\
\hline February & 4.60 & 174.4 & 6.73 & 289.1 \\
\hline March & 4.93 & 169.1 & 6.05 & 237.9 \\
\hline April & 4.89 & 135.0 & 5.57 & 193.3 \\
\hline May & 6.63 & 248.6 & 7.71 & 383.8 \\
\hline June & 7.16 & 281.3 & 8.37 & 447.8 \\
\hline July & 7.78 & 336.7 & 8.98 & 515.1 \\
\hline August & 7.92 & 357.4 & 9.18 & 558.4 \\
\hline September & 6.02 & 297.1 & 6.90 & 443.1 \\
\hline October & 4.93 & 188.1 & 6.48 & 343.1 \\
\hline November & 3.23 & 33.4 & 6.17 & 212.7 \\
\hline December & 1.85 & 69.9 & 3.44 & 380.4 \\
\hline Annual & 5.42 & 206.5 & 6.97 & 373.1 \\
\hline
\end{tabular}

Table 3: Summary of wind data at rameshwaram

\begin{tabular}{|c|c|c|c|c|c|}
\hline Month & Wind speed at $20 \mathrm{~m}$ agl & $\begin{array}{l}\text { Wind power density } \\
\text { at } 20 \mathrm{~m} \text { agl }\left(\mathrm{W} / \mathrm{m}^{2}\right)\end{array}$ & $\begin{array}{l}\text { Peak wind } \\
\text { speed }(\mathrm{m} / \mathrm{sec})\end{array}$ & $\begin{array}{l}\text { Lull hours } \\
\text { wind speed }(\mathrm{m} / \mathrm{sec})\end{array}$ & $\begin{array}{l}\text { Prevailing } \\
\text { direction }\end{array}$ \\
\hline January & 7.25 & 293.0 & 23.24 & 6.110 & $\mathrm{NE}$ \\
\hline February & 5.74 & 161.8 & 15.86 & 16.11 & $\mathrm{NE}$ \\
\hline March & 4.80 & 107.0 & 15.19 & 34.72 & $\mathrm{NE}$ \\
\hline April & 4.96 & 137.8 & 27.71 & 36.38 & S/SW \\
\hline May & 7.49 & 358.6 & 21.45 & 12.77 & S/SW \\
\hline June & 8.83 & 546.3 & 20.55 & 8.610 & SW \\
\hline July & 7.51 & 367.2 & 22.34 & 14.72 & SW \\
\hline August & 6.69 & 256.4 & 18.10 & 11.94 & S/SW \\
\hline September & 6.76 & 288.7 & 19.66 & 18.61 & S/SW \\
\hline October & 5.51 & 177.2 & 21.67 & 30.55 & S/SW \\
\hline November & 6.60 & 234.1 & 21.45 & 15.55 & $\mathrm{NE}$ \\
\hline December & 7.55 & 325.7 & 19.20 & 6.110 & $\mathrm{NE}$ \\
\hline
\end{tabular}

With the good wind sites already taken, these companies are marketing turbines that are ideal for low or medium wind sites. Some of the new players that have forayed into the market include WinWind, a subsidisry of the sterling group; Regen Powertech, a tie-up with Vensys of Germany; Leitner Shriram, a JV between Shriram EPC and Leitwind of Holland; Lanco, collaboration with German company, Sanjay Ghodawat Group, a licensing arrangement with an Austrian company and Kenersys, a Bharat Forge Group Company.

Central Arecanut and Cocoa Marketing and Processing co-operative Ltd. is preparing to become self sufficient in power consumption by setting up a wind energy plant at Hoovina Hadagali in Bellary district of Karnataka. They have signed a Memorandum of Understanding with Suzlon for setting up a $1.25 \mathrm{MW}$ plant that will generate electricity for the consumption of the factory. Approximately Rs. 7 Crores is expected to be invested in this project and the generation cost will be around Rs.1.78 per unit, to which another $7 \%$ will be added as wheeling charge. In all, we will get power at Rs.2.30 a unit, which will control the cost.

Shiriram EPC has tied up with Holland based company Leitwind, to manufacture 1.5 MW capacity wind turbine generators at its Gummdipoondi plant near Chennai. The new company called Leitner Shriram, will manufacture 120 wind turbines per year and raised the capacity to 250 wind turbines from 2010.

WinDForce Management Services Pvt. Ltd. has reported identification of nearly $3,000 \mathrm{MW}$ executable wind farm investment in India. This achievement comes in less than a year of the company launched and is in addition to the achievement of the first 25MW wind farm project being implemented by WinDForce is nearing completion.

Generation of wind power: Energy is a major input for overall socio-economic development. Use of fossil fuels is expected to fuel the economic development process of a majority of the world population during the next two decades. However, at some time during the period 20202050, fossil fuels are likely to reach their maximum potential and their price will become higher than other renewable energy options on account of increasingly constrained production and availability. Therefore, renewable energy since are expected to play a key role in accelerating development and sustainable growth in the second half of the next century, accounting to $50-60 \%$ of the total global energy supply. 
Am. J. Applied Sci., 9 (2): 168-176, 2012

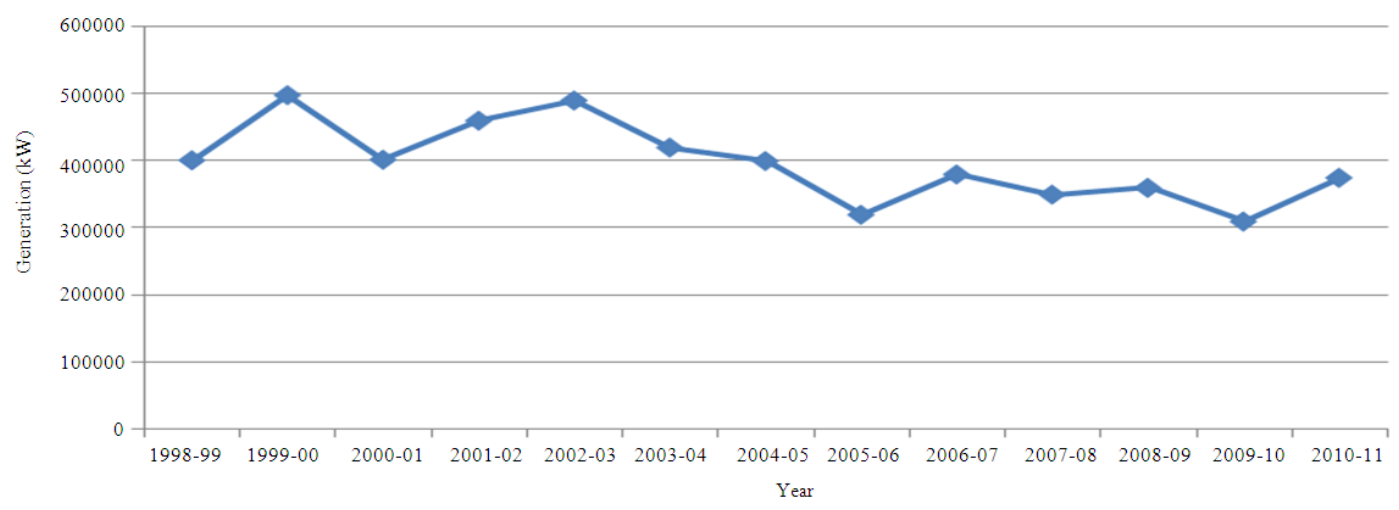

Fig. 2: Muppandal-225kW wind turbines generation details for the period of 1998-2011

After the creation of a separate Ministry in 1992, special emphasis was given in the Eighth Plan to generation of grid quality power from renewables. The total installed capacity of power from renewables today stands at nearly $1350 \mathrm{MW}$ with contribution from wind power of nearly $1000 \mathrm{MW}$.

Ministry of Non-conventional Energy Sources (MNES) are implementing the world's largest wind resource assessment programme, which forms the backbone of their wind exploitation efforts. Preliminary estimates indicate a potential of about 20,000 MW. Scientific surveys are being intensified to identify specific viable and potential sites. A recent study undertaken to re-assess the potential, places it at about 45,000 MW. Assuming a grid penetration of $20 \%$, a technical potential of about 9,000 MW is already available for exploitation in the potential States. 160 sites have so far been identified in 13 States. Survey work is in progress in 24 States.

To strengthen the wind energy technological infrastructure in the country, the Government of India has set up a "Centre for Wind Energy Technology" at Chennai along with a "Wind Turbine Test Station" at Kayathar in Tuticorin District. The Government of Tamil Nadu helped in the establishment of the centre by offering lands at Chennai and Kayathar. The centre will serve as the technical focal point for Wind Power Development in the whole country with the main aim of providing support in the areas of $\mathrm{R}$ and $\mathrm{D}$, Wind Resource Assessment, Type approval, certification, training. To the industry, developers, investors and government authorities in the wind energy sector.

In Muppandal station, monthly generation of 225KW (49 machines) wind turbine average generation details for the period of 1998-2011 is plotted in Fig. 2.

For the purpose of easy comparison, the daily generation has been converted to kilowatt hours per megawatt basis under ideal conditions of $100 \%$ grid availability and $100 \%$ machine availability. The daily generation details of $0.500 \mathrm{MW}$ Ramco Industries Ltd.(RIL-1) at Aralvaimozhi pass, $1.25 \mathrm{MW}$ Ramco Industries Ltd.(RIL-2) at Aralvaimozhi pass, $1.5 \mathrm{MW}$ ACC Ltd. (ACC) at Aralvaimozhi pass, 1.50MW VVD and Sons Pvt Ltd. (VVD Sons) at Aralvaimozhi pass, 0.250MW Tamilnadu Newsprint and Papers Ltd.(TNPL-1) at Shengittah pass, 0.750MW Tamilnadu Newsprint and Papers Ltd.(TNPL-2) at Shengittah pass, Rangamma Steels and Malleables(RSM) AT Palghat pass and $0.230 \mathrm{MW}$ Rajinikanth Foundation(RF) at Karnataka are plotted in Fig. 3-5 the month of September, October and November 2008.

Energy production estimates: The amount of energy that a wind turbine makes each year depends on many factors, but the significant ones are the wind speed at hub-height and the size and type of turbine. The Table 4 gives a rough estimate of the amount of energy that a commercial-scale wind turbine could make. This information may be used to estimate the impact of site choice (i.e., varying wind speeds) and turbine choice (e.g., varying sizes.)

Table 5 details the new industry targets which outline that the annual installation rate will continue to increase, but at lower rates.

The high growth of the last years has been based mainly on the German and Spanish markets. Market forecasts for the next few years indicate that annual installation will stabilise in Spain and will decrease in Germany. A $3.5 \%$ increase in annual installation is assumed for the year 2003, which decreases gradually to $1.3 \%$ in 2010 . This corresponds to a $25.7 \%$ increase in total installed capacity in 2003 gradually decreasing to $10.3 \%$ in the year 2010. Table 6 summarizes the monthly generation details for advanced horizontal axis 1.25 MW wind turbines in wind farms, since the date of commissioning. 


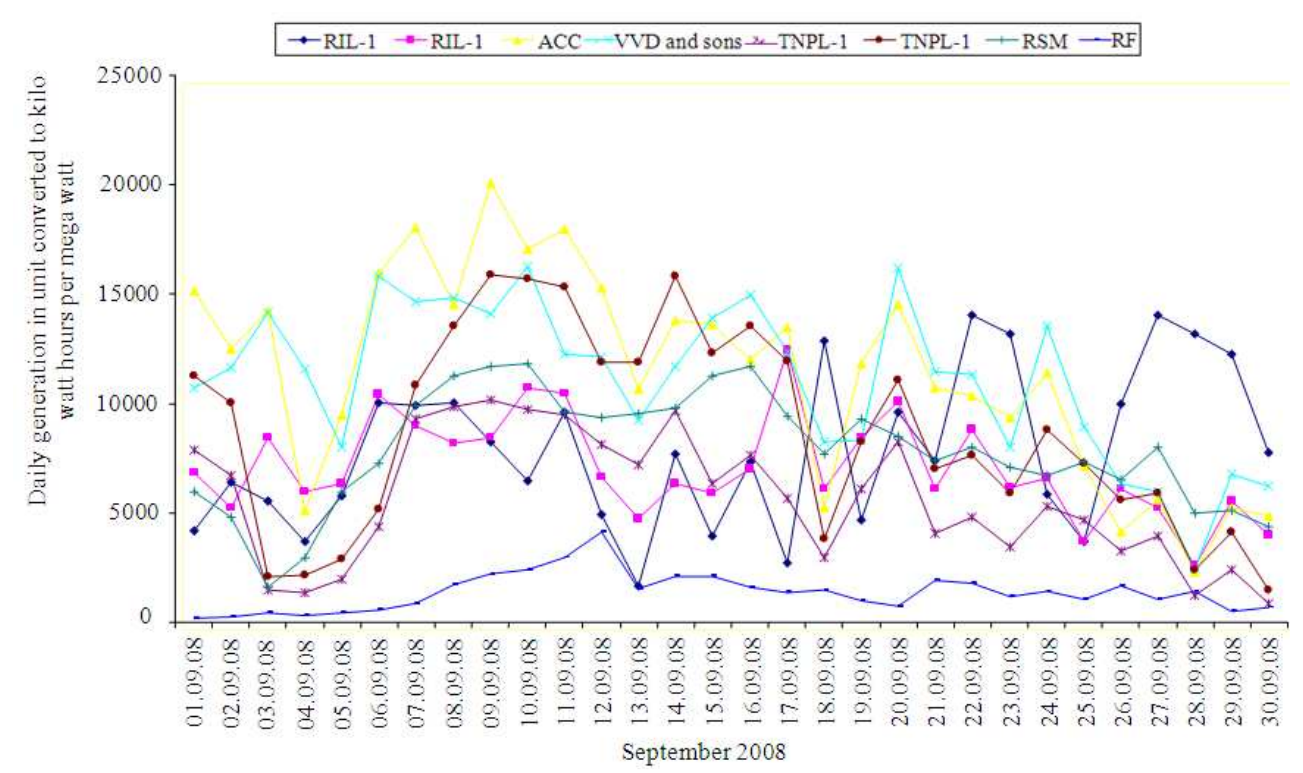

Fig. 3: Wind Monitor graph for the month of September 2008

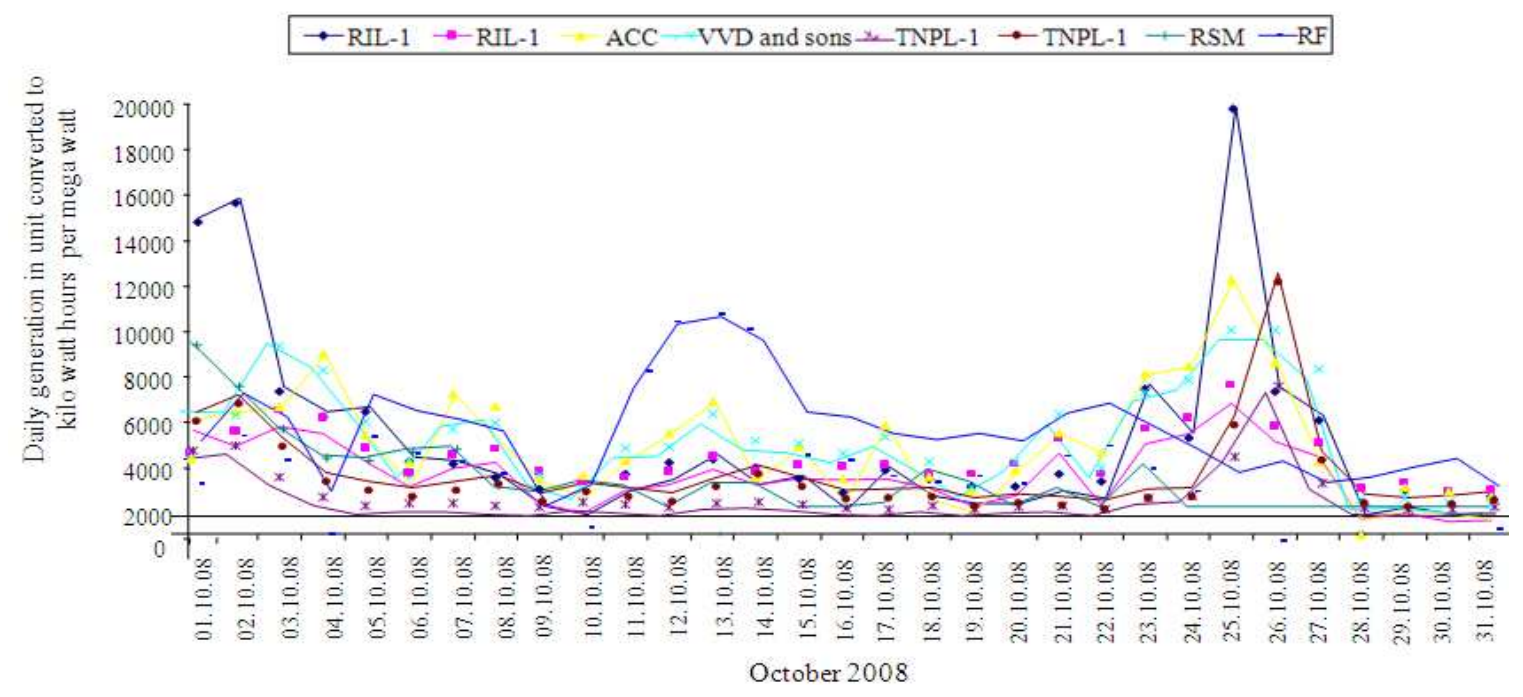

Fig. 4: Wind Monitor graph for the month of October 2008

Table 4: Estimated power generation of 1.5-1.8 MW wind turbine

Annual average Estimated Estimated energy/yr per \begin{tabular}{lll} 
wind speed & capacity factor (\%) & $1.5-1.8 \mathrm{MW}$ turbine in MWh \\
\hline $6.0 \mathrm{~m}$
\end{tabular}

$6.0 \mathrm{~m} \mathrm{sec}^{-1} \quad 22-25 \quad 3,320-3,500$

$6.5 \mathrm{~m} \mathrm{sec}^{-1} \quad 27-30 \quad 3,920-4,190$

$7.0 \mathrm{~m} \mathrm{sec}^{-1} \quad 31-34 \quad 4,500-4,880$

$7.5 \mathrm{~m} \mathrm{sec}^{-1} \quad 35-9 \quad 5,150-5,54$

Thus the maximum annual energy production from 1.25MW wind turbine was estimated as $4272707 \mathrm{kWhr}$ in 2005-2006.The annual energy production since its date of commissioning is plotted in Fig. 6. Based on these real calculations, we concluded that the number of wind electric generators installed by $\mathrm{m} / \mathrm{sec}$. Suzlon Energy Ltd. in Aralvaimozhi, Kanyakumari District is 486 and its total generation detail is tabulated in Table 7 since 2004. At the end of 2011, the company has planned to install 480 additional wind Turbines but due to confidence and wind availability, the Suzlon Energy Ltd. has installed 486 wind generators before Sep'11 with the average grid availability of more than $90 \%$. 
Am. J. Applied Sci., 9 (2): 168-176, 2012

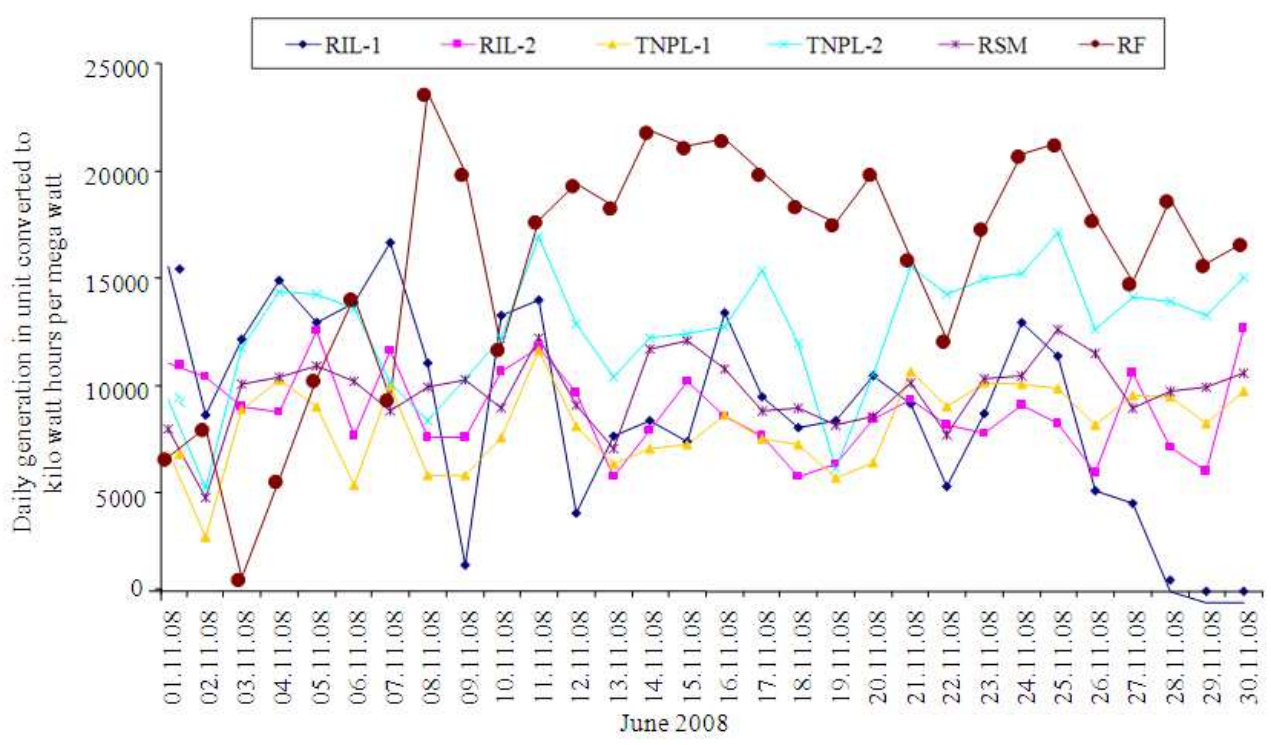

Fig. 5: Wind Monitor graph for the month of November 2008

Table 5: Wind power target projections

\begin{tabular}{|c|c|c|c|c|c|c|c|c|c|c|}
\hline Year & 2001 & 2002 & 2003 & 2004 & 2005 & 2006 & 2007 & 2008 & 2009 & 2010 \\
\hline New capacity (MW) & & 4.500 & 5.700 & 5.900 & 6.100 & 6.300 & 6.450 & 6.60 & 6.750 & 6.900 \\
\hline Cumulative capacity (MW) & 12.800 & 17.300 & 23.000 & 28.900 & 35.000 & 41.300 & 47.750 & 54.35 & 61.100 & 68.000 \\
\hline Annual growth of new capacity & $26.7 \%$ & $3.5 \%$ & $3.4 \%$ & $3.3 \%$ & $2.4 \%$ & $2.3 \%$ & $2.3 \%$ & $2.2 \%$ & & \\
\hline
\end{tabular}

Table 6: Generation details of $1.25 \mathrm{MW}$ wind turbine since the date of commissioning

\begin{tabular}{|c|c|c|c|c|c|c|c|c|c|c|c|c|c|c|c|}
\hline \multicolumn{2}{|c|}{ In 2004-2005 } & \multicolumn{2}{|c|}{ In 2005-2006 } & \multicolumn{2}{|c|}{ In 2006-2007 } & \multicolumn{2}{|c|}{ In $2007-2008$} & \multicolumn{2}{|c|}{ In 2008-2009 } & \multicolumn{2}{|c|}{ In 2009-2010 } & \multicolumn{2}{|c|}{ In $2010-2011$} & \multicolumn{2}{|c|}{ In 2011-2012 } \\
\hline Month & $\begin{array}{l}\text { Genera } \\
\text {-tion }\end{array}$ & Month & $\begin{array}{l}\text { Genera } \\
\text {-tion }\end{array}$ & Month & $\begin{array}{l}\text { Genera } \\
\text {-tion }\end{array}$ & Month & $\begin{array}{l}\text { Genera } \\
\text {-tion }\end{array}$ & Month & $\begin{array}{l}\text { Genera- } \\
\text {-tion }\end{array}$ & Month & $\begin{array}{l}\text { Genera- } \\
\text {-tion }\end{array}$ & Month & $\begin{array}{l}\text { Genera- } \\
\text {-tion }\end{array}$ & Month & $\begin{array}{l}\text { Genera- } \\
\text {-tion }\end{array}$ \\
\hline ---- & ---- & 5-Apr & 101894 & 6-Apr & 144268 & 7-Apr & 73108 & 8-Apr & 135368 & 9-Apr & 62159 & 10-Apr & 85662 & 11-Apr & 100664 \\
\hline ---- & ---- & 5-May & 521040 & 6-May & 413312 & 7-May & 250130 & 8-May & 324860 & 9-May & 351394 & 10-May & 406162 & 11-May & 386188 \\
\hline 4-Jun & 423463 & 4-Jun & 474929 & 6-Jun & 523320 & 7-Jun & 396696 & 8-Jun & 375086 & 9-Jun & 325641 & 10-Jun & 436246 & 11-Jun & 398426 \\
\hline 4-Jul & 381617 & 5-Jul & 447175 & 6-Jul & 573657 & 7-Jul & 416359 & 8-Jul & 491604 & 9-Jul & 311026 & 10-Jul & 388624 & $11-\mathrm{Jul}$ & 416326 \\
\hline 4-Aug & 181032 & 5-Aug & 590542 & 6-Aug & 550475 & 7-Aug & 374777 & 8-Aug & 390843 & 9-Aug & 335549 & 10-Aug & 412668 & 11-Aug & 388947 \\
\hline 4-Sep & 373844 & 5-Sep & 495728 & 6-Sep & 240766 & 7-Sep & 360700 & 8-Sep & 255348 & 9-Sep & 318857 & 10-Sep & 368852 & 11-Sep & 344128 \\
\hline 4-Oct & 161051 & 5-Oct & 229536 & 6-Oct & 179926 & 7-Oct & 166860 & 8-Oct & 203901 & 9-Oct & 142414 & 10-Oct & 182614 & ---- & ---- \\
\hline 4-Nov & 142098 & 5-Nov & 343054 & 6-Nov & 238329 & 7-Nov & 69066 & 8-Nov & 106078 & 9-Nov & 204517 & 10-Nov & 193412 & ---- & ---- \\
\hline 4-Dec & 390215 & 5-Dec & 341143 & 6-Dec & 340363 & 7-Dec & 119633 & 8-Dec & 390182 & 9-Dec & 306164 & 11-Dec & 322126 & ---- & ---- \\
\hline 4-Jan & 408584 & 6-Jan & 335008 & 7-Jan & 221232 & 8-Jan & 241094 & 9-Jan & 336753 & 10-Jan & 350412 & 11-Jan & 281264 & ---- & ---- \\
\hline 5-Feb & 218715 & 6-Feb & 217217 & 7-Feb & 191657 & 8 -Feb & 174608 & 9-Feb & 182234 & $10-\mathrm{Feb}$ & 162864 & 11-Feb & 178326 & ---- & ---- \\
\hline 5-Mar & 120299 & 6-Mar & 175441 & 7-Mar & 110531 & 8-Mar & 54418 & 9-Mar & 70173 & 10-Mar & r 90412 & 11-Mar & 88412 & --- & --- \\
\hline
\end{tabular}

Table 7: Growth rate of wind turbines in aralvaimozhi by suzlon energy Ltd

\begin{tabular}{|c|c|c|c|c|c|c|c|c|c|c|}
\hline Categories & $2002-2003$ & 2003-2004 & 2004-2005 & 2005-2006 & 2006-2007 & 2007-2008 & 2008-2009 & 2009-2010 & 2010-2011 & Up to till now \\
\hline Total machines & 32.00 & 82.00 & 220.00 & 325.00 & 399.00 & 408.00 & 426.00 & 441.00 & 462.00 & 486.00 \\
\hline Total generation & 6554812.001 & 157372390.00 & 411853599.00 & 568491716.00 & 874894829.00 & 472099150.00 & 494833202.00 & 656171122.00 & 724166184.00 & 73189234.00 \\
\hline Average generation & 468201.00 & 3814682.00 & 3156441.00 & 2384354.00 & 2721134.00 & 1255535.00 & 1230928.00 & 1562312.00 & 2386334.00 & 2754126.00 \\
\hline Average m/c Avail & $96.08 \%$ & $96.87 \%$ & $97.68 \%$ & \% $\quad 96.39 \%$ & $97.77 \%$ & $98.42 \%$ & $94.36 \%$ & $\% \quad 95.23 \%$ & $96.84 \%$ & $\% \quad 97.63 \%$ \\
\hline Average Grid Avail & $91.86 \%$ & $96.38 \%$ & $92.84 \%$ & $91.05 \%$ & $92.87 \%$ & $92.13 \%$ & $96.48 \%$ & $91.34 \%$ & $94.86 \%$ & $95.40 \%$ \\
\hline
\end{tabular}

Based on the real calculations, we arrived that for the total wind electric generators installed, the expected economic life for the wind farm is 30 years, based on manufacturers field experience of nearly 15 years. Periodic replacement or refurbishment of major subsystems such as rotor blades or generator windings are assumed to be necessary during the 30-year period, although not all manufacturers claim to require blade replacement in that period. Some researchers feel that sufficient data on component cycle loads, composite material performance prediction and extended operation over a 30-year period do not currently exist to make accurate predictions of lifetime as long as 30 years. 
Am. J. Applied Sci., 9 (2): 168-176, 2012

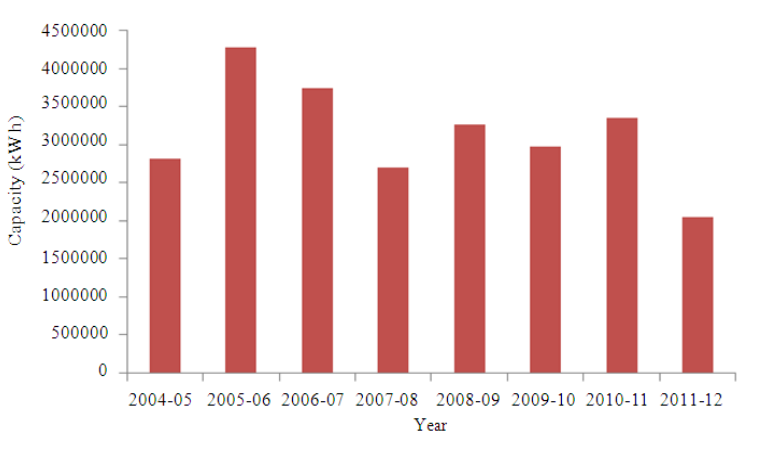

Fig. 6: Energy production summary of $1.25 \mathrm{MW}$ wind turbine

\section{MATERIALS AND METHODS}

The international energy agency predicts that by 2030, more than $28 \%$ of the world's energy consumption will be in India and China.

The energy consumption by India and China exceeds that of the US and therefore, it is essential that a significant part of that energy comes from renewable sources. There has been rapid growth in the installation of wind power in India, especially towards the southern and western states. Almost all the big global manufacturers of wind turbines are present in India with regard to design installation and production of their turbines.

This has contributed to India being the fifth largest installation base for wind turbines in the world as of 2009 (Purohit and Purohit, 2009).

The ministry of new and renewable energy stated the country's wind power potential is $45 \mathrm{GW}$, over the three times of the present installed capacity of 14,550 MW. It is estimated that $6,000 \mathrm{MW}$ of additional wind power capacity will be installed by 2012 . Wind power currently accounts $6 \%$ of total installed capacity, $1.6 \%$ of the country's power.

The Indian Government has announced a generation based incentive for wind energy projects that entitles new wind energy projects to access a benefit of Rs.500 per MWh for the next ten years. This is expected to significantly boost the wind energy capacity addition in the country by providing parity to investors who were not in a position to access the existing fiscal incentives.

For the west coast state, which has an estimated wind power potential of $4,584 \mathrm{MW}$, this would be the highest ever addition in any year to date. Also during the second quarter (July-September) of the current financial year, two onshore wind projects in India were approved. Both projects are in the state of Karnataka, the first project is an 18MW wind farm near Arasinagundi while second is a $21 \mathrm{MW}$ wind farm near Anabaru.

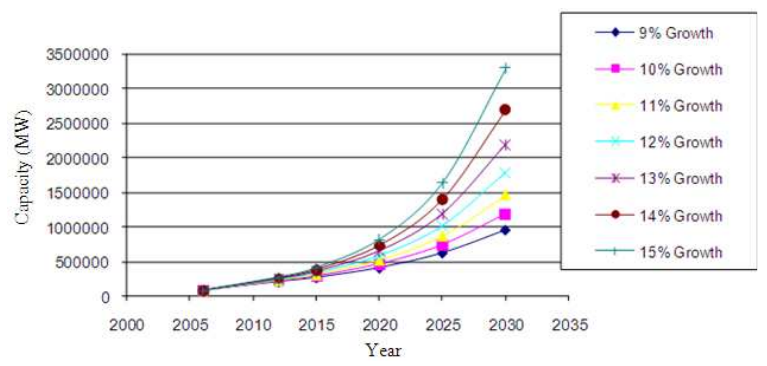

Fig. 7: Projections of installed capacity in India

The International Energy Agency predicts that the world's energy needs will be about $60 \%$ higher than now (International Energy Outlook, 2009). Over the last four years or so, India has added more than $6,300 \mathrm{MW}$ of wind power generation capacity accounting for more than $60 \%$ of the total installed capacity of 9,645 MW. The Fig. 7 presents the total installed capacity needed in India assuming at 9, 10, 11, $12,13,14$ and $15 \%$ growth rates. Even if we go by the lowest growth rate of $9 \%$, situation becomes rather alarming by 2020 .

\section{RESULTS AND DISCUSSION}

Most of the research activities resulting in the new generation of wind turbines are currently being done abroad. This needs to change, as India is not short of fine minds that can take over the mantle. This needs to be facilitated by the industry to carry out these activities within the manufacturers or augmented capacities but certainly within the country. This will assist in the development of more indigenous manufacturers with the capabilities of research and development strengthening and spreading the same within the country.

The implementation of this principle has become more important in the context that there have been issues pertaining to the design done abroad vis-à-vis the requirements pertaining to Indian conditions especially with grid frequency variation, number of grid outages, temperature. One might argue that the Indian conditions could be handled abroad but the core challenge of strengthening minds for research and design activities of wind turbines in India will certainly not be met. This will also assist in another core issue of designing wind turbines suited for lower wind regimes as the availability of most of the potential first class sites is slowly reducing even though re-powering and intercropping concepts are being looked into. The collective initiatives taken will assist India to continually improve the technology without looking for technical aid from outside the country. 
In India, the procedures for testing and certification were put in place in the late 90's with the focus on evaluating the design to ensure safe and optimal performance and also for improving the efficiency of wind turbines. Most of the wind turbines introduced in the market during that period were designed elsewhere with more focus on the conditions prevailing in those countries however design changes are needed to be made in the Indian context. Testing of wind turbine is undertaken by Centre for Wind Energy Technology (CWET) in India. However, testing of major components especially the blades requires major financial resources and is yet to be established. The inter exchange of information during a certification process in India may not be comparable to a growing overseas wind industry due to many reasons. The design of a wind turbine results in design documents which are needed as to be understood for presenting to an agency as per the requirements for evaluating in the light of when these documents were generated and under the gambit of which IEC standard and so on. Therefore, creating awareness and submission of the design documents is also a challenge for the successful certification process in India.

India has gained a lot of experience in ocean technology but is yet to install its first offshore wind turbine. There are a number of offshore wind farms abroad near the coasts of Denmark and Sweden and India is likely to draw upon the experience of these wind farms to establish its first offshore wind turbine. However, establishing an offshore wind turbine and demonstrating its viability is a challenge that India will have to take head on the near future

\section{CONCLUSION}

The modern technology, wind turbine players and development of the wind turbine industry in India emphasizes India's unique strategy of interactive learning for developing wind turbine industry. It clearly indicates as solution to meet the Global requirements through wind turbine industry. The growth clearly shows that how the Indian Government, Non renewable energy sectors and Tamil Nadu help the private sectors to increase the production of wind turbines. Knowledge of the wind velocity at different sites could be used to estimate the wind power, average machine generation and grid availability. This attempts to assess the India's gross potential, position in the world market, wind resource and variation of wind speed with respect to site, different growth rate. Preliminary resource investigation at Rameshwaram and Kanyakumari indicates modest wind along the coastal line. However, it was found that whatever offshore data collected was not continuous and lot of uncertainty was involved as most of it was extrapolated. As such further investigations are required for validation of data collected with an objective to examine the feasibility for setting up of demonstration wind offshore wind farm. This has been an ongoing process to discover the best combination for a given environment in which the wind turbine has to operate and with various challenges met, India would be in a better position to develop and carry forward its own determined initiatives to better the prospects of the wind turbine technology in the coming years. This sectoral innovation systems framework is especially useful tool for analyzing the growth of wind turbine industry and in its essence to preserve the environment with reduction in carbon dioxide emissions.

\section{REFERENCES}

Awesome Inc., 2011. Akshay urja renewable energy. GWEC, 2011. Indian wind energy outlook.

Half Yearly Report,2011. The world wind energy association.

International Energy Outlook, 2009. International Energy Agency (IEA), Paris.

Purohit, I. and P. Purohit, 2009. Wind energy in India: Status and future prospects. J. Renew. Sustain. Energy, 1: 042701. DOI: 10.1063/1.3156003

The Hindu Business Line, 2011. Business daily from the Hindu group of publications. 